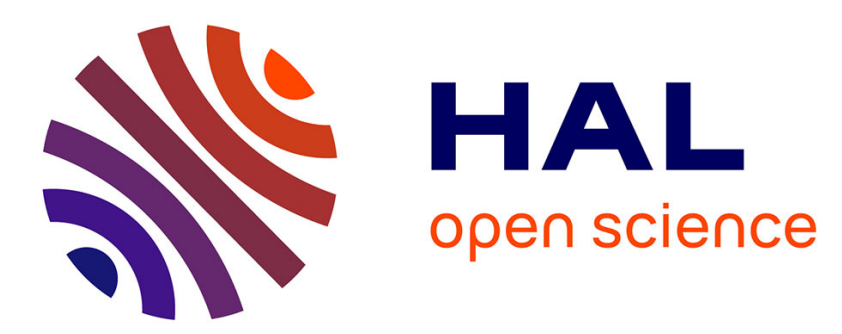

\title{
Phenanthrene decomposition in soil washing effluents using UVB activation of hydrogen peroxide and peroxydisulfate
}

Yufang Tao, Olivier Monfort, Marcello Brigante, Hui Zhang, Gilles Mailhot

\section{- To cite this version:}

Yufang Tao, Olivier Monfort, Marcello Brigante, Hui Zhang, Gilles Mailhot. Phenanthrene decomposition in soil washing effluents using UVB activation of hydrogen peroxide and peroxydisulfate. Chemosphere, 2021, 263, pp.127996. 10.1016/j.chemosphere.2020.127996 . hal-02991542

\section{HAL Id: hal-02991542 \\ https://hal.science/hal-02991542}

Submitted on 17 Nov 2020

HAL is a multi-disciplinary open access archive for the deposit and dissemination of scientific research documents, whether they are published or not. The documents may come from teaching and research institutions in France or abroad, or from public or private research centers.
L'archive ouverte pluridisciplinaire HAL, est destinée au dépôt et à la diffusion de documents scientifiques de niveau recherche, publiés ou non, émanant des établissements d'enseignement et de recherche français ou étrangers, des laboratoires publics ou privés. 


\section{Journal Pre-proof}

Phenanthrene decomposition in soil washing effluents using UVB activation of hydrogen peroxide and peroxydisulfate

Yufang Tao, Olivier Monfort, Marcello Brigante, Hui Zhang, Gilles Mailhot

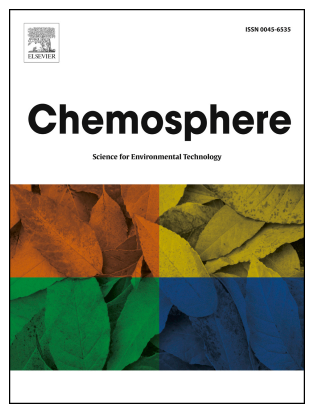

PII:

S0045-6535(20)32191-3

DOI: $\quad$ https://doi.org/10.1016/j.chemosphere.2020.127996

Reference: $\quad$ CHEM 127996

To appear in: $E C S N$

Received Date: 9 April 2020

Revised Date: 8 July 2020

Accepted Date: 10 August 2020

Please cite this article as: Tao, Y., Monfort, O., Brigante, M., Zhang, H., Mailhot, G., Phenanthrene decomposition in soil washing effluents using UVB activation of hydrogen peroxide and peroxydisulfate, Chemosphere, https://doi.org/10.1016/j.chemosphere.2020.127996.

This is a PDF file of an article that has undergone enhancements after acceptance, such as the addition of a cover page and metadata, and formatting for readability, but it is not yet the definitive version of record. This version will undergo additional copyediting, typesetting and review before it is published in its final form, but we are providing this version to give early visibility of the article. Please note that, during the production process, errors may be discovered which could affect the content, and all legal disclaimers that apply to the journal pertain.

(c) 2020 Elsevier Ltd. All rights reserved. 


\begin{abstract}
In this work, the decomposition of phenanthrene (PHE) in mimic and real soil washing (SW) effluents was investigated using UVB light assisted activation of hydrogen peroxide $\left(\mathrm{H}_{2} \mathrm{O}_{2}\right)$ and peroxydisulfate (PDS) oxidation processes. The impact of oxidant concentration, initial $\mathrm{pH}$, and coexisting inorganic anions $\left(\mathrm{Cl}^{-}, \mathrm{HCO}_{3}{ }^{-}\right.$and $\mathrm{NO}_{3}{ }^{-}$) on PHE removal was evaluated. PHE degradation efficiency under UVB irradiation followed the order of UVB/PDS $>\mathrm{UVB} / \mathrm{H}_{2} \mathrm{O}_{2}>\mathrm{UVB}$. The increase of PHE decomposition efficiency was observed with increasing oxidant dose in the range of 2-30 mM upon the two processes. It was found $\mathrm{Cl}^{-}$played different roles in the two activation systems depending on the solution $\mathrm{pH}$ and $\mathrm{Cl}^{-}$concentration. The influence of $\mathrm{HCO}_{3}{ }^{-}$on $\mathrm{PHE}$ elimination was negligible in the UVB/PDS process, while an inhibitory effect was observed in the $\mathrm{UVB} / \mathrm{H}_{2} \mathrm{O}_{2}$ system. Nitrate inhibited the PHE decay in both $\mathrm{UVB} / \mathrm{H}_{2} \mathrm{O}_{2}$ and UVB/PDS processes at the investigated $\mathrm{pH}$ 3.3, 7.1 and 8.6. Finally, the application of the two activation processes to the treatment of real SW effluents indicated that up to $85.0 \%$ of PHE degradation could be reached under $6 \mathrm{~h}$ UVB irradiation with PDS, indicating UVB/PDS process is a promising alternative for SW effluent treatment.
\end{abstract}

Keywords: Soil washing effluent; Phenanthrene; Peroxydisulfate; Hydrogen peroxide; Photodegradation. 
1 Phenanthrene decomposition in soil washing effluents using UVB activation of

\section{hydrogen peroxide and peroxydisulfate}

a Department of Environmental Science and Engineering, Wuhan University, 430079,

China

${ }^{\mathrm{b}}$ Université Clermont Auvergne, CNRS, SIGMA Clermont, Institut de Chimie de Clermont-Ferrand, F-63000 Clermont-Ferrand, France

Corresponding authors: eeng@whu.edu.cn (H. Zhang); gilles.mailhot@uca.fr (G. Mailhot).

\section{Abstract}

In this work, the decomposition of phenanthrene (PHE) in mimic and real soil washing (SW) effluents was investigated using UVB light assisted activation of hydrogen peroxide $\left(\mathrm{H}_{2} \mathrm{O}_{2}\right)$ and peroxydisulfate (PDS) oxidation processes. The impact of oxidant concentration, initial $\mathrm{pH}$, and coexisting inorganic anions $\left(\mathrm{Cl}^{-}, \mathrm{HCO}_{3}{ }^{-}\right.$and $\mathrm{NO}_{3}{ }^{-}$) on PHE removal was evaluated. PHE degradation efficiency under UVB irradiation followed the order of UVB/PDS $>\mathrm{UVB} / \mathrm{H}_{2} \mathrm{O}_{2}>\mathrm{UVB}$. The increase of PHE decomposition efficiency was observed with increasing oxidant dose in the range of 2-30 $\mathrm{mM}$ upon the two processes. It was found $\mathrm{Cl}^{-}$played different roles in the two activation systems depending on the solution $\mathrm{pH}$ and $\mathrm{Cl}^{-}$concentration. The influence of $\mathrm{HCO}_{3}{ }^{-}$on PHE elimination was negligible in the UVB/PDS process, while an inhibitory effect was observed in the $\mathrm{UVB} / \mathrm{H}_{2} \mathrm{O}_{2}$ system. Nitrate inhibited the PHE decay in both $\mathrm{UVB} / \mathrm{H}_{2} \mathrm{O}_{2}$ and UVB/PDS processes at the investigated $\mathrm{pH} 3.3$, 7.1 and 8.6. Finally, the application of the two activation processes to the treatment of real SW effluents indicated that up to $85.0 \%$ of PHE degradation could be reached 
under $6 \mathrm{~h}$ UVB irradiation with PDS, indicating UVB/PDS process is a promising alternative for SW effluent treatment.

Keywords: Soil washing effluent; Phenanthrene; Peroxydisulfate; Hydrogen peroxide; Photodegradation.

\section{Introduction}

Contamination of soils by toxic pollutants, especially by the recalcitrant hydrophobic organic compounds (HOCs) is a matter of significant public, scientific and regulatory concern. Polycyclic aromatic hydrocarbons (PAHs), as a class of HOCs, are ubiquitous in the soil environment due to their low solubility in water and long-term persistence in soils (Manoli and Samara 1999; Shin et al., 2006; Trellu et al., 2016). Phenanthrene (PHE), containing three benzene rings, is one of the most widely detected PAHs in the contaminated sites (Bezza and Chirwa 2017; Gou et al., 2019; Li et al., 2019; Petrová et al., 2017), especially those located in manufactured gas plants and coal tar refinery (Li et al., 2019; Reddy et al., 2006; Yeom et al., 1995). Therefore, it is urgent and essential to develop effective remediation strategies to restore PAHs contaminated soil.

Surfactant-enhanced $e x$-situ soil washing (SW) has been proposed as a promising technology for elimination of PHE from contaminated soils due to its high extraction efficiency and low remediation cost (Kuhlman and Greenfield 1999; Ortega et al., 2008). Among various surfactants, Tween 80 (TW80) was the most commonly used non-ionic surfactant for washing PHE and other PAHs from soil due to its high solubilization capacity, low cost and low toxicity (Cheng et al., 2017; Lamichhane et al., 2017). Nevertheless, the SW process generates a large amount of effluent containing soil pollutant and surfactant, which should be further treated with 
appropriate methods for the complete elimination of soil pollutant (Mousset et al., 2014; Trellu et al., 2017).

In the past few decades, advanced oxidation processes (AOPs) have been developed and widely applied as alternative technologies for the degradation of recalcitrant pollutants in waters and soils (Liu et al., 2016; Mousset et al., 2014; Wan et al., 2018; Wu et al., 2015). This is mainly attributed to the formation of reactive species with high standard redox potential such as hydroxyl radical $\left(\mathrm{HO}^{\circ}, E^{0}=1.8-2.7\right.$ V) or sulfate radical $\left(\mathrm{SO}_{4}{ }^{--}, E^{0}=2.5-3.1 \mathrm{~V}\right)$ (Buxton et al., 1988; Neta et al., 1988). As efficient and environmental friendly techniques, $\mathrm{HO}^{\bullet}$ or $\mathrm{SO}_{4}{ }^{--}$based AOPs have been extensively investigated for the treatment of contaminants in water under UV irradiation (UVA, UVB and UVC) (Huang et al., 2018; Minella et al., 2019; Mosteo et al., 2020; Xiao et al., 2016; Xu et al., 2016; Yang et al., 2016; Zhang et al., 2015; Zhou et al., 2017b). Compared with UVA and UVC, UVB based oxidation has great potential due to: $i$ ) possible use of LED ii) considerably less energy requirement than UVC (Beck et al., 2017) and iii) higher efficiency for contaminant degradation than UVA (Joseph et al., 2016). After reviewing the literature, it is found that the investigation on HOCs decomposition by UVB-based oxidation is pretty limited and no studies for systematic comparison of SW effluent treatment by UVB activation of PDS and $\mathrm{H}_{2} \mathrm{O}_{2}$ are reported before.

The presence of inorganic anions has been reported to exert strong impacts on the oxidative degradation of contaminants (Bennedsen et al., 2012; Liu et al., 2016; Yang et al., 2014). However, the effect of these anions on the photo-degradation of PHE in the SW effluent has not been investigated before. In this study, for the first time, UVB irradiation was used to activate $\mathrm{H}_{2} \mathrm{O}_{2}$ and PDS for PHE decomposition in a surfactant co-existing SW effluent. The aims of this work were: (1) to investigate the PHE 
decomposition efficiency in the present of TW80 by direct UVB radiation, $\mathrm{UVB} / \mathrm{H}_{2} \mathrm{O}_{2}$, and UVB/PDS processes; (2) to evaluate the impact of operating factors including the oxidant dosage, the initial $\mathrm{pH}$ and the coexisting anions on PHE treatment efficiency; (3) to assess the performance of UVB, UVB/ $\mathrm{H}_{2} \mathrm{O}_{2}$ and UVB/PDS systems on PHE oxidation in the real SW solutions.

\section{Materials and methods}

\subsection{Chemicals}

TW80, phenanthrene (PHE), sodium persulfate $\left(\mathrm{Na}_{2} \mathrm{~S}_{2} \mathrm{O}_{8}, \geq 99.0 \%\right.$ ), sodium chorine $(\mathrm{NaCl}, \geq 99.5 \%)$, sodium bicarbonate $\left(\mathrm{NaHCO}_{3}, \geq 99.7 \%\right)$ and sodium nitrate $\left(\mathrm{NaNO}_{3}, \geq 99.0 \%\right)$ were purchased from Sigma-Aldrich. Hydrogen peroxide $\left(\mathrm{H}_{2} \mathrm{O}_{2}\right.$, $30 \%)$ was obtained from Fluka, France. Perchloric acid $\left(\mathrm{HClO}_{4}\right)$ and sodium hydroxide $(\mathrm{NaOH})$ were applied for adjusting the initial $\mathrm{pH}$ of the solutions. Millipore Ultra-Pure System purified water $(18.2 \mathrm{M} \Omega \mathrm{cm})$ was used to prepare solutions. All the chemical reagents were of analytical grade and employed without further purification.

\subsection{Preparation of the mimic and real SW solutions}

One liter of mimic SW solution was prepared as previously reported (Tao et al., 2019). Briefly, $10 \mathrm{mg}$ of PHE was added to $1 \mathrm{~L}$ aqueous solution containing $0.5 \mathrm{~g} \mathrm{~L}^{-1}$ TW80. The mixed solution was vigorously stirred for one week to obtain complete PHE dissolution before irradiation experiments.

Natural soil samples were obtained from Wuhan of Hubei Province (soil 1), Chuzhou of Anhui Province (soil 2) and Huaian of Jiangsu Province (soil 3), respectively. The collected soils were air dried and ground to obtain particles less than $2 \mathrm{~mm}$ before use. The PHE contaminated soil samples were prepared according to the literature (Yang et al., 2006). Briefly, the three PHE free soils were spiked with PHE dissolved in acetone 
solutions and vigorously stirred for 30 minutes to obtain homogeneous distribution of PHE in the soil. The spiked soil samples were placed in three hoods for 5 days at room temperature to evaporate the solvent. The final PHE concentrations of each spiked soil were $4000 \mathrm{mg} \mathrm{kg}^{-1}$.

To obtain the real SW solutions, 3 grams of each contaminated soil were separately weighed into $150 \mathrm{~mL}$ conical flasks with stoppers and $60 \mathrm{~mL}$ TW80 solutions $\left(10 \mathrm{~g} \mathrm{~L}^{-1}\right)$ were added. The flasks were then placed into a constant temperature shaker for $24 \mathrm{~h}$ with a speed of $200 \mathrm{rpm}$ at $25{ }^{\circ} \mathrm{C}$. Then, the mixtures were centrifuged at $8000 \mathrm{rpm}$ for $15 \mathrm{~min}$ and the supernatants were filtered with $0.22 \mu \mathrm{m}$ PTFE filters before analysis and the sequent irradiation experiments.

\subsection{Irradiation experiments}

Irradiations experiments were carried out in a cylindrical Pyrex reactor $(100 \mathrm{~mL})$ which was placed into a rectangular glass jacket vessel with cooling water flowing between interlayers ensuring a constant temperature of $20 \pm 2{ }^{\circ} \mathrm{C}$ through a thermostat-controlled cooling system. Four UVB tubes (G15T8E, Japan) were fixed on the top of the photo-reactor as the light resource, and the distance between photoreactor and the lamps was around $24 \mathrm{~cm}$. The schematic diagram of experimental set-up is shown in Figure S1.

The polychromatic UVB irradiation energy was recorded by an optical fiber with a charge coupled device spectrophotometer (Ocean Optics USD $2000+$ UV-vis). The total irradiance reaching the solution was then estimated to be $1393 \mu \mathrm{W} \mathrm{cm}{ }^{-2}$ in the UVB range (between 270 and $400 \mathrm{~nm}$ ). The absorption spectra of PDS, $\mathrm{H}_{2} \mathrm{O}_{2}$ and PHE solution in TW80 were recorded with a UV-visible spectrophotometer Cary 300. Emission spectrum of adopted UVB lamps reaching the solution was recorded using a calibrated CCD camera (Huang et al., 2018) as presented in Figure S2. 
During the irradiation, the SW solution was continuously magnetically stirred at a

124 fixed speed with a magnetic stirrer. At fixed interval times, $1 \mathrm{~mL}$ of sample was

125 withdrawn and analyzed by a high performance liquid chromatography (HPLC,

126 Alliance) equipped with a Waters 2998 photodiode array detector. The flow rate was 1

$127 \mathrm{~mL} \mathrm{~min}^{-1}$ and an isocratic elution with water and acetonitrile $(15 / 85, \mathrm{v} / \mathrm{v})$ was used.

128 The column was a Nucleodur $100-5 \mathrm{C} 18$ of $150 \mathrm{~mm} \times 4.6 \mathrm{~mm}$, with particle size of 5 $129 \mu \mathrm{m}$.

130 The pseudo-first order rate constant of PHE decomposition $\left(k_{1}\right)$ was determined 131 from Eq. (1):

$$
[\mathrm{PHE}] /[\mathrm{PHE}]_{0}=\exp \left(-k_{1} t\right)
$$

where $[\mathrm{PHE}]_{0}$ and $[\mathrm{PHE}]$ were the PHE initial concentration and PHE concentration at time $t$, respectively.

Inorganic components of three real SW effluents were determined by ion chromatography. For anions, a Dionex DX320 system equipped with an IonPac AS11 column and a $\mathrm{KOH}$ elution in gradient mode were used. For cations, a Dionex ICS-1500 system equipped an Ion-Pac CS16 column and a metasulfonic acid (MSA) eluent were employed (Marion et al., 2018).

TW80 concentration after soil washing process was quantified by a spectrophotometric method using cobalt ammonium thiocyanate as the chromogenic agent (Crabb and Persinger 1964).

\section{Results and discussion}

\subsection{Comparison of UVB activation of $\mathrm{H}_{2} \mathrm{O}_{2}$ and PDS}

In Figure 1, the decomposition of PHE $\left(10 \mathrm{mg} \mathrm{L}^{-1}\right.$ corresponding to $\sim 56 \mu \mathrm{M}$ in 0.5 $\mathrm{g} \mathrm{L}^{-1}$ TW80 solution) is reported. Under direct photolysis (UVB alone), about $23.0 \%$ 
of PHE decay was observed after $3 \mathrm{~h}$ irradiation with a first order rate constant $\left(k_{1}\right)$ of $1.5 \times 10^{-3} \mathrm{~min}^{-1}$, which is equivalent to a half-life of $7.8 \mathrm{~h}$ (Table S4). When the oxidant $\left(\mathrm{H}_{2} \mathrm{O}_{2}\right.$ or PDS $)$ was applied to the irradiation system, $\mathrm{HO}^{\bullet}$ and $\mathrm{SO}_{4}{ }^{--}$were generated through photo-dissociation of $\mathrm{H}_{2} \mathrm{O}_{2}$ and PDS under UVB irradiation (Eqs. 2 and 3) (Mark et al., 1990; Yu and Barker 2003).

$$
\begin{aligned}
& \mathrm{S}_{2} \mathrm{O}_{8}{ }^{2-}+h v \rightarrow 2 \mathrm{SO}_{4}{ }^{--} \\
& \mathrm{H}_{2} \mathrm{O}_{2}+h v \rightarrow 2 \mathrm{HO}^{\circ}
\end{aligned}
$$

The evolution of HPLC chromatograms during $\mathrm{UVB} / \mathrm{H}_{2} \mathrm{O}_{2}$ and UVB/PDS processes is presented in Figure S3, and PHE removal reached up to $34.0 \%$ and $72.0 \%$, respectively. The pseudo-first order rate constants were $2.3 \times 10^{-3} \mathrm{~min}^{-1}$ with $\mathrm{H}_{2} \mathrm{O}_{2}$ and $7.1 \times 10^{-3} \min ^{-1}$ with PDS. The correspondent half-lives of PHE were calculated to be $5.0 \mathrm{~h}$ and $1.6 \mathrm{~h}$ in the $\mathrm{UVB} / \mathrm{H}_{2} \mathrm{O}_{2}$ and $\mathrm{UVB} / \mathrm{PDS}$ systems, respectively (Table S4). The different performance between $\mathrm{UVB} / \mathrm{H}_{2} \mathrm{O}_{2}$ and UVB/PDS systems could be ascribed to the following aspects. Firstly, the photo-dissociation quantum yield of PDS is higher than that for $\mathrm{H}_{2} \mathrm{O}_{2}$. In fact, near the maximum emission wavelength of UVB (313 nm in Figure S2), the reported $\mathrm{SO}_{4}{ }^{-}$ formation quantum yield from PDS photolysis $\left(\Phi_{\mathrm{SO}_{4}}{ }^{-}\right)$is $1.1 \pm 0.2$ (Herrmann 2007 ), which is higher than the quantum yield for $\mathrm{HO}^{\bullet}$ generation from $\mathrm{H}_{2} \mathrm{O}_{2}$, i.e., $0.98 \pm 0.2$ (Zellner et al., 1990) or $0.8 \pm 0.2$ (Yu and Barker 2003) at the wavelength of $308 \mathrm{~nm}$. Secondly, the selectivity of $\mathrm{SO}_{4}{ }^{--}$towards PHE is superior to that of $\mathrm{HO}^{\bullet}$ (Tao et al., 2019). To verify this point, the selectivity coefficient $\zeta_{\text {PHE }}$ is defined as Eq. (4) based on the reactions of radicals with PHE, TW80 (Eqs. 5-8) and other species in the system (see Text S1).

$$
\zeta_{\mathrm{PHE}}=\frac{k_{\mathrm{X}^{*}, \mathrm{PHE}}[\mathrm{PHE}]_{0}}{k_{\mathrm{X}^{*}, \mathrm{PHE}}[\mathrm{PHE}]_{0}+k_{\mathrm{X}^{*}, \mathrm{~S}}[\mathrm{~S}]_{0}}
$$


171

172 173 and $[\mathrm{S}]_{0}$ are their initial concentrations.

174

\subsection{Effect of oxidant concentration}

where $k_{\mathrm{X}^{*}, \mathrm{PHE}}$ and $k_{\mathrm{X}^{*}, \mathrm{~S}}$ are the second order rate constants of radicals with PHE and other components S (PHE, TW80, oxidant, etc.) in the system, respectively. $[\mathrm{PHE}]_{0}$

$$
\begin{aligned}
& \mathrm{PHE}+\mathrm{HO}^{\circ} \rightarrow \text { products } \quad k_{\mathrm{HO}}, \mathrm{PHE}=6.1 \times 10^{9} \mathrm{M}^{-1} \mathrm{~s}^{-1} \\
& \mathrm{PHE}+\mathrm{SO}_{4}{ }^{-} \rightarrow \text { products } \quad k_{\mathrm{SO}_{4}^{-}, \mathrm{PHE}}=4.3 \times 10^{9} \mathrm{M}^{-1} \mathrm{~s}^{-1} \\
& \mathrm{TW} 80+\mathrm{HO}^{\circ} \rightarrow \text { products } \quad k_{\mathrm{HO}^{*}, \mathrm{TW} 80}=9.9 \times 10^{9} \mathrm{M}^{-1} \mathrm{~s}^{-1} \\
& \mathrm{TW} 80+\mathrm{SO}_{4}{ }^{--} \rightarrow \text { products } \quad k_{\mathrm{SO}_{4}^{--}, \mathrm{TW} 80}=4.6 \times 10^{9} \mathrm{M}^{-1} \mathrm{~s}^{-1}
\end{aligned}
$$

In the $\mathrm{UVB} / \mathrm{H}_{2} \mathrm{O}_{2}$ system, $\mathrm{HO}^{\bullet}$ is the main generated radical, and $\zeta_{\mathrm{PHE}}$ was calculated to be around $8.1 \%$, while the selectivity coefficient was about $12.1 \%$ in the UVB/PDS system with $\mathrm{SO}_{4}{ }^{-}$as the major radical. This means the selectivity coefficient $\zeta_{\mathrm{PHE}}$ for $\mathrm{SO}_{4}{ }^{--}$towards $\mathrm{PHE}(12.1 \%)$ is about 1.5 times higher than that of $\mathrm{HO}^{\bullet}(8.1 \%)$. The result confirms $\mathrm{SO}_{4}{ }^{--}$was more selective than $\mathrm{HO}^{\bullet}$ to the oxidation of PHE in the presence of TW80 (Tao et al., 2019). Lastly, the rate constant of $\mathrm{H}_{2} \mathrm{O}_{2}$ and $\mathrm{HO}^{\bullet}$ is around 43 times higher than that of PDS and $\mathrm{SO}_{4}{ }^{-}\left(k_{\mathrm{HO}^{*}, \mathrm{H}_{2} \mathrm{O}_{2}}=2.7 \times 10^{7} \mathrm{M}^{-1}\right.$ $\mathrm{s}^{-1}, k_{\mathrm{SO}_{4}^{--}, \mathrm{S}_{2} \mathrm{O}_{8}^{2-}}=6.3 \times 10^{5} \mathrm{M}^{-1} \mathrm{~s}^{-1}$ ), indicating $\mathrm{HO}^{\bullet}$ would be more prone to be quenched by $\mathrm{H}_{2} \mathrm{O}_{2}$ than $\mathrm{SO}_{4}{ }^{-}$scavenged by PDS (Eqs. 9 and 10).

$$
\begin{aligned}
& \mathrm{HO}^{-}+\mathrm{H}_{2} \mathrm{O}_{2} \rightarrow \mathrm{H}_{2} \mathrm{O}+\mathrm{HO}_{2}{ }^{\cdot} \quad k_{\mathrm{HO}^{*}, \mathrm{H}_{2} \mathrm{O}_{2}}=2.7 \times 10^{7} \mathrm{M}^{-1} \mathrm{~s}^{-1} \\
& \mathrm{SO}_{4}^{-{ }^{--}+\mathrm{S}_{2} \mathrm{O}_{8}{ }^{2-} \rightarrow \mathrm{SO}_{4}{ }^{2-}+\mathrm{S}_{2} \mathrm{O}_{8}^{--}} k_{\mathrm{SO}_{4}^{--}, \mathrm{S}_{2} \mathrm{O}_{8}^{2-}}=6.3 \times 10^{5} \mathrm{M}^{-1} \mathrm{~s}^{-1}
\end{aligned}
$$

Effects of initial concentration of $\mathrm{H}_{2} \mathrm{O}_{2}$ or PDS on PHE degradation were evaluated as reported in Figure 2. In the $\mathrm{UVB} / \mathrm{H}_{2} \mathrm{O}_{2}$ process, it can be seen from Figure $2 \mathrm{~A}$ that PHE decomposition after 3 hours reached around $28.0 \%$ with $2 \mathrm{mM} \mathrm{H}_{2} \mathrm{O}_{2}$ and $51.0 \%$ with $30 \mathrm{mM} \mathrm{H} \mathrm{H}_{2} \mathrm{O}_{2}$, and the corresponding PHE oxidation rate constant increased around 1.95 folds from $2.0 \times 10^{-3}$ to $3.9 \times 10^{-3} \mathrm{~min}^{-1}$. In the UVB/PDS process as 
195 illustrated in Figure 2B, with $2 \mathrm{mM}$ of PDS, the PHE decomposition efficiency

196 reached around $61.0 \%$ and rate constant was $5.1 \times 10^{-3} \mathrm{~min}^{-1}$. With further addition of

197 PDS to $30 \mathrm{mM}$, the PHE elimination efficiency was around $83.0 \%$ and $k_{1}$ increased

198 around 1.90 folds to $9.7 \times 10^{-3} \mathrm{~min}^{-1}$. In comparison with the effect of oxidant type,

199 the results indicated that the decomposition efficiency of PHE followed the order of

200 PDS $>\mathrm{H}_{2} \mathrm{O}_{2}$ at the same oxidant dosage.

201 Some researchers reported that the decomposition rate of contaminant increased

202 linearly with the oxidant dosage (Deng et al., 2013; Tan et al., 2013; Xu et al., 2016),

203 while others found that the removal rate would drop when the oxidant concentration

204 exceeds its threshold level (Olmez-Hanci and Arslan-Alaton 2013; Yang et al., 2010;

205 Zhou et al., 2017a). In our case, PHE removal increased almost linearly with

206 increasing $\mathrm{H}_{2} \mathrm{O}_{2}$ concentration from 2 to $30 \mathrm{mM}$, probably because more $\mathrm{HO}^{\circ}$ radcials

207 were formed for PHE decomposition with higher $\mathrm{H}_{2} \mathrm{O}_{2}$ concentration and the

208 maximum dosage $(30 \mathrm{mM})$ was still below its threshold level. In the UVB/PDS

209 system, PHE removal efficiency also increased with the increasement of PDS.

210 However, insignificant improvement of PHE decomposition was observed at PDS

211 concentration higher than $10 \mathrm{mM}$, which possibly because the PDS concentration was

212 beyond the threshold and quenching effect of $\mathrm{SO}_{4}{ }^{-}$radicals via Eq. (10) (Herrmann

213 et al., 1995) became pronounced.

\subsection{Effect of initial pH}

The influence of initial $\mathrm{pH}$ on the photo-degradation of $\mathrm{PHE}$ by the $\mathrm{UVB} / \mathrm{H}_{2} \mathrm{O}_{2}$ and $\mathrm{UVB} / \mathrm{PDS}$ processes is given in Figure 3. In the $\mathrm{UVB} / \mathrm{H}_{2} \mathrm{O}_{2}$ system, a slight difference (less than $10.0 \%$ ) was obtained from $\mathrm{pH} 3.3$ to $\mathrm{pH} 10.1$, though the maximum PHE decomposition extent of $40.0 \%$ and a first order rate constant of $2.8 \times 10^{-3} \mathrm{~min}^{-1}$ were 
219 observed at $\mathrm{pH} 4.5$ (Figure 3A). In the UVB/PDS system, $\mathrm{pH}$ had insignificant effect

220 on PHE decay, and the difference of PHE photo-degradation efficiency was less than

$2215.0 \%$ with $\mathrm{pH}$ value ranging from acidic to basic (Figure 3B). The little difference of

222 PHE degradation with $\mathrm{pH}$ is probably due to the chemical stability of PHE with $\mathrm{pH}$

223 ranging from 3.3 to 10.1 and also the photolysis of $\mathrm{H}_{2} \mathrm{O}_{2}$ or PDS is not pH dependent.

224 Moreover, although the PHE degradation was performed in a quite wide initial $\mathrm{pH}$ 225 range (from 3.3 to 10.1 ), the $\mathrm{pH}$ varied from 3.4 to 6.6 after $\mathrm{UVB} / \mathrm{H}_{2} \mathrm{O}_{2}$ process, or from

(3.3 3.8) in the UVB/PDS system is less than that (3.4 6.6) in the $\mathrm{UVB} / \mathrm{H}_{2} \mathrm{O}_{2}$ system.

It is probably due to the higher degradation efficiency of PHE and more production of acidic intermediates in the UVB/PDS system than in the $\mathrm{UVB} / \mathrm{H}_{2} \mathrm{O}_{2}$ system.

\subsection{Effect of inorganic anions}

Inorganic species (such as carbonate, chloride and nitrate) are widely found in the soil due to many factors: (i) the parent soil substrate, (ii) depositions through fertilization, and (iii) other human activities such as irrigation (Du et al., 2013; Wang et al., 2019). These anions are generally considered to be freely mobile in soils and can be released into groundwater via rainfall (Bastviken et al., 2006; Lu et al., 2019). Therefore, inorganic species $\left(\mathrm{Cl}^{-}, \mathrm{HCO}_{3}{ }^{-}\right.$and $\left.\mathrm{NO}_{3}{ }^{-}\right)$are inevitably dissolved in the SW effluent and they may exert impact on the PHE decomposition by $\mathrm{UVB} / \mathrm{H}_{2} \mathrm{O}_{2}$ and UVB/PDS processes.

\subsubsection{Chloride} adverse effect on the two AOPs. In the $\mathrm{UVB} / \mathrm{H}_{2} \mathrm{O}_{2}$ process as shown in Figure $4 \mathrm{~A}$, the 
inhibited by around $10.0 \%$ with addition of $50 \mathrm{mM} \mathrm{Cl}^{-}$. In the UVB/PDS process as depicted in Figure 4B, PHE oxidation gradually increased by $9.0 \%$ when $\mathrm{Cl}^{-}$ concentration ranging from 0 to $10 \mathrm{mM}$ and no further improvement of PHE removal can be achieved with $50 \mathrm{mM} \mathrm{Cl}^{-}$. At $\mathrm{pH} 7.1$, the influence of $\mathrm{Cl}^{-}$from 2 to $50 \mathrm{mM}$ on PHE removal is negligible in the $\mathrm{UVB} / \mathrm{H}_{2} \mathrm{O}_{2}$ system (Figure $\mathrm{S} 4 \mathrm{~A}$ ), while PHE removal increased by $15.0 \%$ with $\mathrm{Cl}^{-}$dose varying from 0 to $50 \mathrm{mM}$ in the UVB/PDS process (Figure S4B). At alkaline $\mathrm{pH} 8.6, \mathrm{Cl}^{-}$exerted negative effect on $\mathrm{PHE}$ oxidation and larger inhibition was observed with higher $\mathrm{Cl}^{-}$concentration in the $\mathrm{UVB} / \mathrm{H}_{2} \mathrm{O}_{2}$ system and PHE decomposition decreased by $17.0 \%$ in the presence of 50 $\mathrm{mM} \mathrm{Cl}^{-}$(Figure S4C). Under the same $\mathrm{pH}$ condition, the effect of $2 \mathrm{mM} \mathrm{Cl}^{-}$on $\mathrm{PHE}$ removal was insignificant and PHE removal was slightly promoted by around $6.0 \%$ with 10 and $50 \mathrm{mM} \mathrm{Cl}^{-}$in the UVB/PDS system (Figure S4D).

Various conflicting results were reported in the different UV based AOPs with the presence of $\mathrm{Cl}^{-}$as indicated in Table $\mathrm{S} 1$. Usually, $\mathrm{Cl}^{-}$can react with $\mathrm{HO}^{\circ}$ and $\mathrm{SO}_{4}{ }^{-}$to yield secondary active chlorine radical species such as $\mathrm{ClOH}^{\circ-}, \mathrm{Cl}^{\bullet}$, and $\mathrm{Cl}_{2}{ }^{--}$through a series of intricate chain reactions (Eqs. 11, 13-15) (Grigor'ev et al., 1987; Jayson et al., 1973; Neta et al., 1988).

$$
\begin{aligned}
& \mathrm{HO}^{*}+\mathrm{Cl}^{-} \rightarrow \mathrm{ClOH}^{-} \quad k_{\mathrm{HO}^{\circ}, \mathrm{Cl}^{-}}=4.3 \times 10^{9} \mathrm{M}^{-1} \mathrm{~s}^{-1} \\
& \mathrm{ClOH}^{--} \rightarrow \mathrm{Cl}^{-}+\mathrm{HO}^{\cdot} \quad k_{\mathrm{ClOH}^{--}, \mathrm{ClOH}^{--}}=6.1 \times 10^{9} \mathrm{M}^{-1} \mathrm{~s}^{-1} \\
& \mathrm{ClOH}^{-}+\mathrm{H}^{+} \rightarrow \mathrm{Cl}^{\bullet}+\mathrm{H}_{2} \mathrm{O} \quad k_{\mathrm{ClOH}^{-}, \mathrm{H}^{+}}=2.1 \times 10^{10} \mathrm{M}^{-1} \mathrm{~s}^{-1} \\
& \mathrm{Cl}^{\cdot}+\mathrm{Cl}^{-} \rightarrow \mathrm{Cl}_{2}{ }^{--} \quad k_{\mathrm{Cl}^{\circ}, \mathrm{Cl}^{-}}=2.1 \times 10^{10} \mathrm{M}^{-1} \mathrm{~s}^{-1} \\
& \mathrm{ClOH}^{-}+\mathrm{Cl}^{-} \rightarrow \mathrm{Cl}_{2}{ }^{--}+\mathrm{HO}^{-} \quad k_{\mathrm{ClOH}^{--}, \mathrm{Cl}^{-}}=1.0 \times 10^{4} \mathrm{M}^{-1} \mathrm{~s}^{-1} \\
& \mathrm{Cl}_{2}{ }^{--}+\mathrm{PHE} \rightarrow \text { byproducts } \quad k_{\mathrm{Cl}_{2}^{-}, \mathrm{PHE}}=4.6 \times 10^{8} \mathrm{M}^{-1} \mathrm{~s}^{-1}
\end{aligned}
$$

The negligible effect of low $\mathrm{Cl}^{-}$concentration $(2-10 \mathrm{mM})$ on PHE removal in the $\mathrm{UVB} / \mathrm{H}_{2} \mathrm{O}_{2}$ system was mainly due to the reaction of Eq. (12). The negative effect of 
$26950 \mathrm{mM} \mathrm{Cl}^{-}$on PHE oxidation observed can be ascribed to the consumption of $\mathrm{H}_{2} \mathrm{O}_{2}$

270 by $\mathrm{Cl}^{\circ}$ and $\mathrm{Cl}_{2}{ }^{--}$(Eqs.17 and 18) (Hasegawa and Neta 1978; Kläning and Wolff 1985).

271 These reactions reduced the amount of available $\mathrm{HO}^{\circ}$ and $\mathrm{Cl}_{2}{ }^{-}$radicals reacting with

272 PHE (Eqs.5 and 16) (Tao et al., 2019), leading to the lower PHE elimination.

273 Moreover, the finding of inhibition of PHE at $\mathrm{pH} 8.6$ could be explained by the 274 reduction of $\mathrm{Cl}_{2}{ }^{--}$triggered by Eqs. (19) and also the higher consumption of $\mathrm{H}_{2} \mathrm{O}_{2}$ via 275 Eqs. (17) and (18) at alkaline pH, which restrained active species reacting with PHE 276 and consequently retarded PHE oxidation.

$$
\begin{array}{ll}
\mathrm{Cl}^{\bullet}+\mathrm{H}_{2} \mathrm{O}_{2} \rightarrow \mathrm{H}^{+}+\mathrm{Cl}^{-}+\mathrm{HO}_{2}^{\cdot} & k_{\mathrm{Cl}^{\bullet}, \mathrm{H}_{2} \mathrm{O}_{2}}=2.0 \times 10^{9} \mathrm{M}^{-1} \mathrm{~s}^{-1} \\
\mathrm{Cl}_{2}^{--}+\mathrm{H}_{2} \mathrm{O}_{2} \rightarrow \mathrm{HO}_{2}^{-}+\mathrm{H}^{+}+2 \mathrm{Cl}^{-} & k_{\mathrm{Cl}_{2}^{--}, \mathrm{H}_{2} \mathrm{O}_{2}}=1.4 \times 10^{5} \mathrm{M}^{-1} \mathrm{~s}^{-1} \\
\mathrm{Cl}_{2}{ }^{--}+\mathrm{HO}^{-} \rightarrow \mathrm{ClOH}^{--}+\mathrm{Cl}^{-} & k_{\mathrm{Cl}^{-}, \mathrm{HO}^{-}}=4.5 \times 10^{7} \mathrm{M}^{-1} \mathrm{~s}^{-1}
\end{array}
$$

In the UVB/PDS system, the weak enhancement of PHE decay was attributed to the production of $\mathrm{Cl}_{2}{ }^{--}$radicals through a series of chain reactions (Eqs.14 and 20). According to our previous study (Tao et al., 2019), $\mathrm{Cl}_{2}{ }^{-{ }^{-}}$was more selective towards PHE than $\mathrm{SO}_{4}{ }^{--}$in the presence of TW80 (Eqs. 16 and 21), therefore PHE elimination could be promoted.

$$
\begin{array}{ll}
\mathrm{SO}_{4}{ }^{-{ }^{-}}+\mathrm{Cl}^{-} \rightarrow \mathrm{SO}_{4}{ }^{2-}+\mathrm{Cl}^{\cdot} & k_{\mathrm{SO}_{4}^{--}, \mathrm{Cl}^{-}}=4.7 \times 10^{8} \mathrm{M}^{-1} \mathrm{~s}^{-1} \\
\mathrm{Cl}_{2}{ }^{-}+\mathrm{TW} 80 \rightarrow \text { byproducts } & k_{\mathrm{Cl}_{2}^{-}, \mathrm{TW} 80}=7.1 \times 10^{6} \mathrm{M}^{-1} \mathrm{~s}^{-1}
\end{array}
$$

\subsubsection{Bicarbonate}

Figure 5 depicts the elimination efficiency of PHE in the presence of various concentrations of bicarbonate $\left(\mathrm{HCO}_{3}{ }^{-}\right)$in the $\mathrm{UVB} / \mathrm{H}_{2} \mathrm{O}_{2}$ and $\mathrm{UVB} / \mathrm{PDS}$ processes at initial $\mathrm{pH}$ of around 8.6. As presented in Figure 5A, the oxidation of PHE was obviously inhibited with the addition of $\mathrm{HCO}_{3}{ }^{-}$, which is in accordance with most reports investigated in aqueous phase in the absence of surfactant (Table S2). With the addition of $50 \mathrm{mM}$ bicarbonate, the PHE removal efficiency decreased by almost 
one-half in comparison with $33.0 \%$ removal in the absence of bicarbonate. $\mathrm{HCO}_{3}{ }^{-}$ could react with $\mathrm{HO}^{\circ}$ to generate carbonate radicals $\left(\mathrm{CO}_{3}{ }^{-{ }^{-}}\right)$via Eq. (22). However, the generated $\mathrm{CO}_{3}{ }^{--}$are considered to be a weaker oxidant and the reactions with most organic pollutants are insignificant (Crittenden et al., 1999; Zuo et al., 1999). As a consequence, available $\mathrm{HO}^{\circ}$ was reduced and PHE decomposition was depressed.

$$
\mathrm{HCO}_{3}{ }^{-}+\mathrm{HO}^{\bullet} \rightarrow \mathrm{H}_{2} \mathrm{O}+\mathrm{CO}_{3}^{-{ }^{-}} \quad k_{\mathrm{HO}^{\bullet}, \mathrm{HCO}_{3}^{-}}=8.5 \times 10^{6} \mathrm{M}^{-1} \mathrm{~s}^{-1}
$$

The effect of bicarbonate in the UVB/PDS system is illustrated in Figure 5B. Insignificant effect of $\mathrm{HCO}_{3}{ }^{-}$was observed, which may be ascribed to the negligible scavenging effect of $\mathrm{SO}_{4}{ }^{--}$by $\mathrm{HCO}_{3}{ }^{-}$(Eq. 23) since the rate constant between $\mathrm{SO}_{4}{ }^{-}$ and $\mathrm{HCO}_{3}{ }^{-}$is around 3 orders of magnitudes smaller than that between PHE and $\mathrm{SO}_{4}{ }^{--}$. In the meanwhile, the little influence of $\mathrm{HCO}_{3}{ }^{-}$on the performance of UVB/PDS system was ascribed to the unpronounced variation of selectivity coefficient $(12.1 \% \sim 11.3 \%)$ with the $\mathrm{HCO}_{3}{ }^{-}$concentration ranging from $0 \sim 50 \mathrm{mM}$.

$$
\mathrm{HCO}_{3}{ }^{-}+\mathrm{SO}_{4}{ }^{--} \rightarrow \mathrm{SO}_{4}{ }^{2-}+\mathrm{CO}_{3}^{--}+\mathrm{H}^{+} k_{\mathrm{SO}_{4}^{--}, \mathrm{HCO}_{3}^{-}}=2.8 \times 10^{6} \mathrm{M}^{-1} \cdot \mathrm{s}^{-1}
$$

\subsubsection{Nitrate}

The influence of $\mathrm{NO}_{3}^{-}$with different doses and $\mathrm{pH}$ conditions on the decomposition of PHE in the UVB/PDS and $\mathrm{UVB} / \mathrm{H}_{2} \mathrm{O}_{2}$ systems were studied. $\mathrm{NO}_{3}{ }^{-}$ led to a strong inhibitory effect on the two AOPs, which is in agreement with other reports as summarized in Table S3. At $\mathrm{pH} 3.3$, with the concentration of $\mathrm{NO}_{3}{ }^{-}$ranging from 0 to $50 \mathrm{mM}$, the PHE decomposition efficacy decreased from $34.5 \%$ to $19.0 \%$ in the $\mathrm{UVB} / \mathrm{H}_{2} \mathrm{O}_{2}$ system (Figure 6A), while it dropped from $73.0 \%$ to $42.0 \%$ in the UVB/PDS system (Figure 6B).

The stronger inhibition of $\mathrm{NO}_{3}{ }^{-}$on PHE decomposition can be explained by the screen effect of light due to the photoreactivity of $\mathrm{NO}_{3}{ }^{-}$(Eqs. 24 and 25) (Keen et al., 2012) and its secondary substance (i.e. $\mathrm{NO}_{2}{ }^{-}$), leading to competition with $\mathrm{H}_{2} \mathrm{O}_{2}$ and 
PDS for UVB radiation. It is reported that both $\mathrm{NO}_{3}{ }^{-}$and $\mathrm{NO}_{2}{ }^{-}$have absorption in the range of UVB light (around $260-330 \mathrm{~nm}$ ) (Mack and Bolton 1999). This is supported by the strong decrease of the direct photolysis of PHE under UVB irradiation in presence of $5 \mathrm{mM} \mathrm{NO}_{3}{ }^{-}$. In the UVB alone, PHE removal was $23.0 \%$ while it dropped to only $7.0 \%$ with the addition of $5 \mathrm{mM} \mathrm{NO}_{3}{ }^{-}$. The production of $\mathrm{HO}^{\bullet}$ from the $\mathrm{NO}_{3}{ }^{-}$and $\mathrm{NO}_{2}{ }^{-}$photolysis (Eqs. 26-28) (Keen et al., 2012; Lyon et al., 2012; Sörensen and Frimmel 1997) probably did not compensate the negative screen effect. On the other hand, $\mathrm{NO}_{3}{ }^{-}$and $\mathrm{NO}_{2}{ }^{-}$had quenching effect for both $\mathrm{SO}_{4}{ }^{--}$and $\mathrm{HO}^{\circ}$ via Eqs. (29)-(31), which could also restrain PHE degradation.

$$
\begin{array}{ll}
\mathrm{NO}_{3}{ }^{-}+h v \rightarrow \mathrm{NO}_{2}{ }^{-}+\mathrm{O}^{-} \\
\mathrm{NO}_{3}{ }^{-}+h v \rightarrow \mathrm{NO}_{2}{ }^{-}+1 / 2 \mathrm{O}_{2} \\
\mathrm{NO}_{3}{ }^{-}+\mathrm{H}^{+}+h v \rightarrow \mathrm{HO}^{\bullet}+\mathrm{NO}_{2}{ }^{-}
\end{array}
$$

The influence of $5 \mathrm{mM} \mathrm{NO}_{3}{ }^{-}$on PHE degradation at different initial $\mathrm{pH}$ was also investigated in the two AOPs. As displayed in Figure S5, in comparison with the absence of $\mathrm{NO}_{3}{ }^{-}$, the decrease of PHE removal at $\mathrm{pH} 3.3,7.1$ and 8.6 was respectively $5.0 \%, 14.5 \%, 13.6 \%$ in the $\mathrm{UVB} / \mathrm{H}_{2} \mathrm{O}_{2}$ system, while it was respectively $10.7 \%, 10.3 \%$ and $14.3 \%$ in the UVB/PDS system.

\subsection{Treatment of real SW effluent by the $\mathrm{UVB} / \mathrm{H}_{2} \mathrm{O}_{2}$ and UVB/PDS systems}


The treatment of real effluents after washing three types of soils spiked with PHE

was further carried out to evaluate the feasibility of $\mathrm{UVB} / \mathrm{H}_{2} \mathrm{O}_{2}$ and $\mathrm{UVB} / \mathrm{PDS}$ systems. The various ions and constituents in the soils are listed in Table S6, and the results of SW effluent treatment are displayed in Figure 7. As can be seen, UVB/PDS system was more effective for PHE decomposition than $\mathrm{UVB} / \mathrm{H}_{2} \mathrm{O}_{2}$ and $\mathrm{UVB}$ alone for the three SW samples, corroborating our former results with mimic SW samples. Direct PHE photolysis in the UVB system was less than $10.0 \%$ for all the three SW effluents. The lower efficiency compared with synthetic SW samples (around 23.0\%) could be ascribed to the screening effect of light due to the diverse mixture of substances in the solution. For $\mathrm{UVB} / \mathrm{H}_{2} \mathrm{O}_{2}$ or UVB/PDS process the efficiencies of PHE degradation in the SW effluents from soil 1 and 2 were comparable with those in the synthetic SW effluents, while for soil 3, the PHE removal efficiency was lower in both $\mathrm{UVB} / \mathrm{H}_{2} \mathrm{O}_{2}$ and UVB/PDS systems. In fact, with $\mathrm{H}_{2} \mathrm{O}_{2}$, PHE degradation efficiencies after $6 \mathrm{~h}$ irradiation were $47.5 \%, 51.6 \%$ and $33.5 \%$ in soil 1,2 and 3 respectively. With PDS the removal of PHE achieved around $85.0 \%$ for soil 1 and 2 and $78.0 \%$ for soil 3 .

The results of PHE degradation with the three real SW effluents using the two AOPs validated our previous observations on the mimic SW solutions and the effects of the main co-existing inorganic species. Moreover, although the intricate mixed effects of the various soil components in real SW effluent, the PHE oxidation efficiency with UVB/PDS is similar to the removal in the synthetic solutions, implying UVB/PDS remains to be the most efficient process for PHE elimination.

\section{Conclusion}

The results obtained from this study indicate that the UVB based AOPs, e.g., $\mathrm{UVB} / \mathrm{PDS}$ and $\mathrm{UVB} / \mathrm{H}_{2} \mathrm{O}_{2}$, can eliminate PHE in both simulated and real SW 
367 effluents. The photo-degradation efficiency of PHE is influenced by various 368 parameters including the concentration of oxidants, initial $\mathrm{pH}$ and widespread soil 369 inorganic anions $\left(\mathrm{Cl}^{-}, \mathrm{HCO}_{3}{ }^{-}\right.$and $\left.\mathrm{NO}_{3}{ }^{-}\right)$. Opposite results are obtained for the effect 370 of $\mathrm{Cl}^{-}$for $\mathrm{UVB}$ assisted $\mathrm{H}_{2} \mathrm{O}_{2}$ and PDS activation. The presence of $\mathrm{Cl}^{-}$at alkaline $\mathrm{pH}$ 371 inhibits PHE degradation in $\mathrm{UVB} / \mathrm{H}_{2} \mathrm{O}_{2}$, while slightly enhances PHE elimination in the UVB/PDS process at different $\mathrm{pH}$. The experimental results reveal the negligible effect of $\mathrm{HCO}_{3}{ }^{-}$in the $\mathrm{UVB} / \mathrm{PDS}$ system but negative effect in the $\mathrm{UVB} / \mathrm{H}_{2} \mathrm{O}_{2}$ process. Nitrate has negative effect on the PHE degradation in both AOPs. Overall, the $\mathrm{UVB} / \mathrm{PDS}$ process is much more efficient than $\mathrm{UVB} / \mathrm{H}_{2} \mathrm{O}_{2}$ due to the formation of sulfate radical which is less sensitive to the main inorganic ions present in soil, and could be a promising process to be applied for real SW effluents treatment.

\section{Acknowledgments}

Authors gratefully acknowledge the Ministry of Education of China for providing financial support to Yufang TAO for her stay at the Institute of Chemistry of Clermont-Ferrand and Clermont Auvergne University in France. Authors also acknowledge the financial support from the Region Council of Auvergne Rhône Alpes, from the "Féderation des Recherches en Environnement" through the CPER CAP 20-25 I-site project.

\section{References}

Bastviken, D., Sandén, P., Svensson, T., Ståhlberg, C., Magounakis, M., Öberg, G., 2006. Chloride retention and release in a boreal forest soil: effects of soil water residence time and nitrogen and chloride loads. Environmental Science \& 
Technology 40 (9), 2977-2982.

392

393

Beck, S.E., Ryu, H., Boczek, L.A., Cashdollar, J.L., Jeanis, K.M., Rosenblum, J.S., Lawal, O.R., Linden, K.G., 2017. Evaluating UV-C LED disinfection performance and investigating potential dual-wavelength synergy. Water Research 109, 207-216.

Bennedsen, L.R., Muff, J., Sogaard, E.G., 2012. Influence of chloride and carbonates on the reactivity of activated persulfate. Chemosphere 86 (11), 1092-1097.

Bezza, F.A., Chirwa, E.M.N., 2017. The role of lipopeptide biosurfactant on microbial remediation of aged polycyclic aromatic hydrocarbons (PAHs)-contaminated soil. Chemical Engineering Journal 309, 563-576.

Buxton, G.V., Greenstock, C.L., Helman, W.P., Ross, A.B., 1988. Critical review of rate constants for reactions of hydrated electrons, hydrogen atoms and hydroxyl radicals $\left(\cdot \mathrm{OH} / \cdot \mathrm{O}^{-}\right)$in aqueous solution. Journal of Physical and Chemical Reference Data 17 (2), 513-886.

Cheng, M., Zeng, G., Huang, D., Yang, C., Lai, C., Zhang, C., Liu, Y., 2017. Advantages and challenges of Tween 80 surfactant-enhanced technologies for the remediation of soils contaminated with hydrophobic organic compounds. Chemical Engineering Journal 314, 98-113.

Crabb, N.T., Persinger, H.E., 1964. The determination of polyoxyethylene nonionic surfactants in water at the parts per million level. Journal of the American Oil Chemists' Society 41 (11), 752-755.

Crittenden, J.C., Hu, S., Hand, D.W., Green, S.A., 1999. A kinetic model for $\mathrm{H}_{2} \mathrm{O}_{2} / \mathrm{UV}$ process in a completely mixed batch reactor. Water Research 33 (10), 2315-2328.

Deng, J., Shao, Y., Gao, N., Xia, S., Tan, C., Zhou, S., Hu, X., 2013. Degradation of the antiepileptic drug carbamazepine upon different UV-based advanced 
oxidation processes in water. Chemical Engineering Journal 222, 150-158.

417

418

Du, C., Ma, Z., Zhou, J., Goyne, K.W., 2013. Application of mid-infrared photoacoustic spectroscopy in monitoring carbonate content in soils. Sensors and Actuators, B: Chemical 188, 1167-1175.

Gou, Y., Yang, S., Cheng, Y., Song, Y., Qiao, P., Li, P., Ma, J., 2019. Enhanced anoxic biodegradation of polycyclic aromatic hydrocarbons (PAHs) in aged soil pretreated by hydrogen peroxide. Chemical Engineering Journal 356, 524-533.

Grigor'ev, A., Makarov, I., Pikaev, A., 1987. Formation of $\mathrm{Cl}_{2}^{-}$in the bulk of solution during radiolysis of concentrated aqueous solutions of chlorides. Khimiya Vysokikh Ehnergij 21 (2), 123-126.

Hasegawa, K., Neta, P., 1978. Rate constants and mechanisms of reaction of chloride $\left(\mathrm{Cl}_{2}{ }^{-}\right)$radicals. The Journal of Physical Chemistry 82 (8), 854-857.

Herrmann, H., 2007. On the photolysis of simple anions and neutral molecules as sources of $\mathrm{O}^{-} / \mathrm{OH}, \mathrm{SO}_{\mathrm{x}}^{-}$and $\mathrm{Cl}$ in aqueous solution. Physical Chemistry Chemical Physics 9 (30), 3935-3964.

Herrmann, H., Reese, A., Zellner, R., 1995. Time-resolved UV/Vis diode array absorption spectroscopy of $\mathrm{SO}_{\mathrm{x}}^{-}(\mathrm{x}=3,4,5)$ radical anions in aqueous solution. Journal of Molecular Structure 348, 183-186.

Huang, W., Bianco, A., Brigante, M., Mailhot, G., 2018. UVA-UVB activation of hydrogen peroxide and persulfate for advanced oxidation processes: efficiency, mechanism and effect of various water constituents. Journal of Hazardous Materials 347, 279-287.

Jayson, G., Parsons, B., Swallow, A.J., 1973. Some simple, highly reactive, inorganic chlorine derivatives in aqueous solution. their formation using pulses of radiation and their role in the mechanism of the fricke dosimeter. Journal of The Chemical 
Society, Faraday Transactions 1: Physical Chemistry in Condensed Phases 69, $1597-1607$.

443

444

445

Joseph, C.G., Taufiq-Yap, Y.H., Li Puma, G., Sanmugam, K., Quek, K.S., 2016. Photocatalytic degradation of cationic dye simulated wastewater using four radiation sources, UVA, UVB, UVC and solar lamp of identical power output. Desalination and Water Treatment 57 (17), 7976-7987.

Keen, O.S., Love, N.G., Linden, K.G., 2012. The role of effluent nitrate in trace organic chemical oxidation during UV disinfection. Water Research 46 (16), 5224-5234.

Kläning, U.K., Wolff, T., 1985. Laser flash photolysis of $\mathrm{HCIO}, \mathrm{CIO}^{-}, \mathrm{HBrO}$, and $\mathrm{BrO}^{-}$in aqueous solution. reactions of $\mathrm{Cl}^{-}$and $\mathrm{Br}^{-}$atoms. Berichte der Bunsengesellschaft für Physikalische Chemie 89 (3), 243-245.

Kuhlman, M., Greenfield, T., 1999. Simplified soil washing processes for a variety of soils. Journal of Hazardous Materials 66 (1-2), 31-45.

Lamichhane, S., Bal Krishna, K.C., Sarukkalige, R., 2017. Surfactant-enhanced remediation of polycyclic aromatic hydrocarbons: A review. Journal of Environmental Management 199, 46-61.

Li, Y., Liao, X., Huling, S.G., Xue, T., Liu, Q., Cao, H., Lin, Q., 2019. The combined effects of surfactant solubilization and chemical oxidation on the removal of polycyclic aromatic hydrocarbon from soil. Science of The Total Environment 647, 1106-1112.

Liu, Y., He, X., Duan, X., Fu, Y., Fatta-Kassinos, D., Dionysiou, D.D., 2016. Significant role of UV and carbonate radical on the degradation of oxytetracycline in UV-AOPs: kinetics and mechanism. Water Research 95, 195-204. 
Lu, J., Bai, Z., Velthof, G.L., Wu, Z., Chadwick, D., Ma, L., 2019. Accumulation and leaching of nitrate in soils in wheat-maize production in China. Agricultural Water Management 212, 407-415.

Lyon, B.A., Dotson, A.D., Linden, K.G., Weinberg, H.S., 2012. The effect of inorganic precursors on disinfection byproduct formation during UV-chlorine/chloramine drinking water treatment. Water Research 46 (15), 4653-4664.

Mack, J., Bolton, J.R., 1999. Photochemistry of nitrite and nitrate in aqueous solution: a review. Journal of Photochemistry and Photobiology A 128 (1), 1-13.

Manoli, E., Samara, C., 1999. Polycyclic aromatic hydrocarbons in natural waters: sources, occurrence and analysis. Trends in Analytical Chemistry 18 (6), 417-428.

Marion, A., Brigante, M., Mailhot, G., 2018. A new source of ammonia and carboxylic acids in cloud water: The first evidence of photochemical process involving an iron-amino acid complex. Atmospheric Environment 195, 179-186.

Mark, G., Schuchmann, M.N., Schuchmann, H., von Sonntag, C., 1990. The photolysis of potassium peroxodisulphate in aqueous solution in the presence of tert-butanol: a simple actinometer for $254 \mathrm{~nm}$ radiation. Journal of Photochemistry and Photobiology A 55 (2), 157-168.

Minella, M., Bertinetti, S., Hanna, K., Minero, C., Vione, D., 2019. Degradation of ibuprofen and phenol with a Fenton-like process triggered by zero-valent iron (ZVI-Fenton). Environmental Research 179, 108750.

Mosteo, R., Varon-Lopez, A., Muzard, D., Benitez, N., Giannakis, S., Pulgarin, C., 2020. Visible light plays a significant role during bacterial inactivation by the photo-Fenton process, even at sub-critical light intensities. Water Research, 
491

492

493

494

495

496

497

498

499

500

501

502

503

504

505

506

507

508

509

510

511

512

513

514

515

115636.

Mousset, E., Oturan, N., Hullebusch, E.D.V., Guibaud, G., Esposito, G., Oturan, M.A., 2014. Influence of solubilizing agents (cyclodextrin or surfactant) on phenanthrene degradation by electro-Fenton process - study of soil washing recycling possibilities and environmental impact. Water Research 48 (1), 306-316.

Neta, P., Huie, R.E., Ross, A.B., 1988. Rate constants for reactions of inorganic radicals in aqueous solution. Journal of Physical and Chemical Reference Data $17(3), 1027-1284$.

Olmez-Hanci, T., Arslan-Alaton, I., 2013. Comparison of sulfate and hydroxyl radical based advanced oxidation of phenol. Chemical Engineering Journal 224, 10-16.

Ortega, L.M., Lebrun, R., Blais, J., Hausler, R., Drogui, P., 2008. Effectiveness of soil washing, nanofiltration and electrochemical treatment for the recovery of metal ions coming from a contaminated soil. Water Research 42 (8-9), 1943-1952.

Petrová, Š., Rezek, J., Soudek, P., Vaněk, T., 2017. Preliminary study of phytoremediation of brownfield soil contaminated by PAHs. Science of The Total Environment 599, 572-580.

Reddy, K.R., Ala, P.R., Sharma, S., Kumar, S.N., 2006. Enhanced electrokinetic remediation of contaminated manufactured gas plant soil. Engineering Geology 85 (1-2), 132-146.

Shin, K.-H., Kim, K.-W., Ahn, Y., 2006. Use of biosurfactant to remediate phenanthrene-contaminated soil by the combined solubilization-biodegradation process. Journal of Hazardous Materials 137 (3), 1831-1837.

Sörensen, M., Frimmel, F.H., 1997. Photochemical degradation of hydrophilic xenobiotics in the $\mathrm{UVH}_{2} \mathrm{O}_{2}$ process: Influence of nitrate on the degradation rate 
of EDTA, 2-amino-1-naphthalenesulfonate, diphenyl-4-sulfonate and 4, 4'-diaminostilbene-2, 2'-disulfonate. Water Research 31 (11), 2885-2891.

518

Tan, C., Gao, N., Deng, Y., Zhang, Y., Sui, M., Deng, J., Zhou, S., 2013. Degradation of antipyrine by UV, UV/ $\mathrm{H}_{2} \mathrm{O}_{2}$ and UV/PS. Journal of Hazardous Materials 260, 1008-1016.

Tao, Y., Brigante, M., Zhang, H., Mailhot, G., 2019. Phenanthrene degradation using Fe (III)-EDDS photoactivation under simulated solar light: A model for soil washing effluent treatment. Chemosphere 236, 124366.

Trellu, C., Ganzenko, O., Papirio, S., Pechaud, Y., Oturan, N., Huguenot, D., Van Hullebusch, E.D., Esposito, G., Oturan, M.A., 2016. Combination of anodic oxidation and biological treatment for the removal of phenanthrene and Tween 80 from soil washing solution. Chemical Engineering Journal 306, 588-596.

Trellu, C., Oturan, N., Pechaud, Y., van Hullebusch, E.D., Esposito, G., Oturan, M.A., 2017. Anodic oxidation of surfactants and organic compounds entrapped in micelles - Selective degradation mechanisms and soil washing solution reuse. Water Research 118, 1.

Wan, D., Zuo, J., Chen, Y., Chen, Q., Zuo, Y., 2018. Photodegradation of amitriptyline in $\mathrm{Fe}(\mathrm{III})$-citrate-oxalate binary system: Synergistic effect and mechanism. Chemosphere 210, 224-231.

Wang, C., Shu, L., Zhou, S., Yu, H., Zhu, P., 2019. Effects of alternate partial root-zone irrigation on the utilization and movement of nitrates in soil by tomato plants. Scientia Horticulturae 243, 41-47.

Wu, Y., Bianco, A., Brigante, M., Dong, W., de Sainte-Claire, P., Hanna, K., Mailhot, G., 2015. Sulfate radical photogeneration using Fe-EDDS: influence of critical parameters and naturally occurring scavengers. Environmental Science \& 
Technology 49 (24), 14343-14349.

542 Xiao, Y., Zhang, L., Zhang, W., Lim, K., Webster, R.D., Lim, T., 2016. Comparative 543 evaluation of iodoacids removal by $\mathrm{UV} /$ persulfate and $\mathrm{UV} / \mathrm{H}_{2} \mathrm{O}_{2}$ processes. $544 \quad$ Water Research 102, 629-639.

545 Xu, Y., Lin, Z., Zhang, H., 2016. Mineralization of sucralose by UV-based advanced oxidation processes: UV/PDS versus $\mathrm{UV} / \mathrm{H}_{2} \mathrm{O}_{2}$. Chemical Engineering Journal

Yang, K., Zhu, L., Xing, B., 2006. Enhanced soil washing of phenanthrene by mixed solutions of TX100 and SDBS. Environmental Science \& Technology 40 (13),

Yang, S., Wang, P., Yang, X., Shan, L., Zhang, W., Shao, X., Niu, R., 2010. Degradation efficiencies of azo dye acid orange 7 by the interaction of heat, UV and anions with common oxidants: persulfate, peroxymonosulfate and hydrogen peroxide. Journal of Hazardous Materials 179 (1-3), 552-558.

Yang, Y., Pignatello, J.J., Ma, J., Mitch, W.A., 2014. Comparison of halide impacts on the efficiency of contaminant degradation by sulfate and hydroxyl radical-based advanced oxidation processes (AOPs). Environmental Science \& Technology 48 (4), 2344-2351.

Yang, Y., Pignatello, J.J., Ma, J., Mitch, W.A., 2016. Effect of matrix components on $\mathrm{UV} / \mathrm{H}_{2} \mathrm{O}_{2}$ and $\mathrm{UV} / \mathrm{S}_{2} \mathrm{O}_{8}{ }^{2-}$ advanced oxidation processes for trace organic degradation in reverse osmosis brines from municipal wastewater reuse facilities. Water Research 89, 192-200.

Yeom, I.T., Ghosh, M.M., Cox, C.D., Robinson, K.G., 1995. Micellar solubilization of polynuclear aromatic hydrocarbons in coal tar-contaminated soils. Environmental Science \& Technology 29 (12), 3015-3021. 
Yu, X.-Y., Barker, J.R., 2003. Hydrogen peroxide photolysis in acidic aqueous solutions containing chloride ions. II. Quantum yield of $\mathrm{HO} \bullet(\mathrm{Aq})$ radicals. Journal of Physical Chemistry A 107 (9), 1325-1332.

Zellner, R., Exner, M., Herrmann, H., 1990. Absolute OH quantum yields in the laser photolysis of nitrate, nitrite and dissolved $\mathrm{H}_{2} \mathrm{O}_{2}$ at 308 and $351 \mathrm{~nm}$ in the temperature range 278-353 K. Journal of Atmospheric Chemistry 10 (4), 411-425.

Zhang, R., Sun, P., Boyer, T.H., Zhao, L., Huang, C.-H., 2015. Degradation of pharmaceuticals and metabolite in synthetic human urine by $\mathrm{UV}, \mathrm{UV} / \mathrm{H}_{2} \mathrm{O}_{2}$, and UV/PDS. Environmental Science \& Technology 49 (5), 3056-3066.

Zhou, L., Ferronato, C., Chovelon, J., Sleiman, M., Richard, C., 2017a. Investigations of diatrizoate degradation by photo-activated persulfate. Chemical Engineering Journal 311, 28-36.

Zhou, L., Sleiman, M., Ferronato, C., Chovelon, J., Sainte-claire, P.D., Richard, C., 2017b. Sulfate radical induced degradation of $\beta 2$-adrenoceptor agonists salbutamol and terbutaline: Phenoxyl radical dependent mechanisms. Water research $123,715-723$.

Zuo, Z., Cai, Z., Katsumura, Y., Chitose, N., Muroya, Y., 1999. Reinvestigation of the acid-base equilibrium of the (bi) carbonate radical and $\mathrm{pH}$ dependence of its reactivity with inorganic reactants. Radiation Physics and Chemistry 55 (1), $15-23$. 


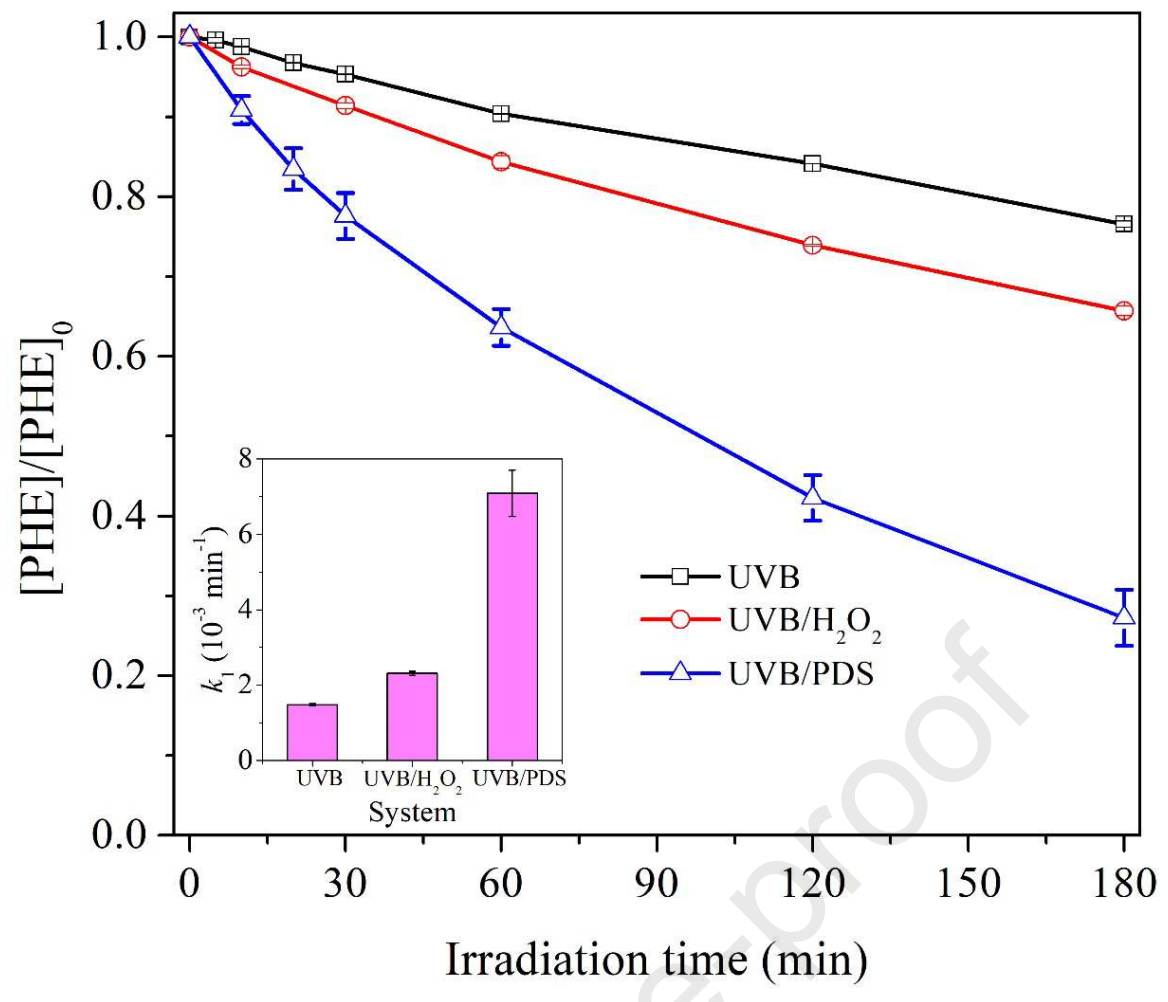

Figure 1. Degradation of PHE in the presence of TW80 in different systems. Inserts are the corresponding pseudo-first order rate constants. Initial conditions are $[\mathrm{PHE}]=$ $10 \mathrm{mg} \mathrm{L}^{-1},[\mathrm{TW} 80]=0.5 \mathrm{~g} \mathrm{~L}^{-1},[\mathrm{PDS}]=\left[\mathrm{H}_{2} \mathrm{O}_{2}\right]=5 \mathrm{mM}, \mathrm{pH} 3.3 \pm 0.1$. 

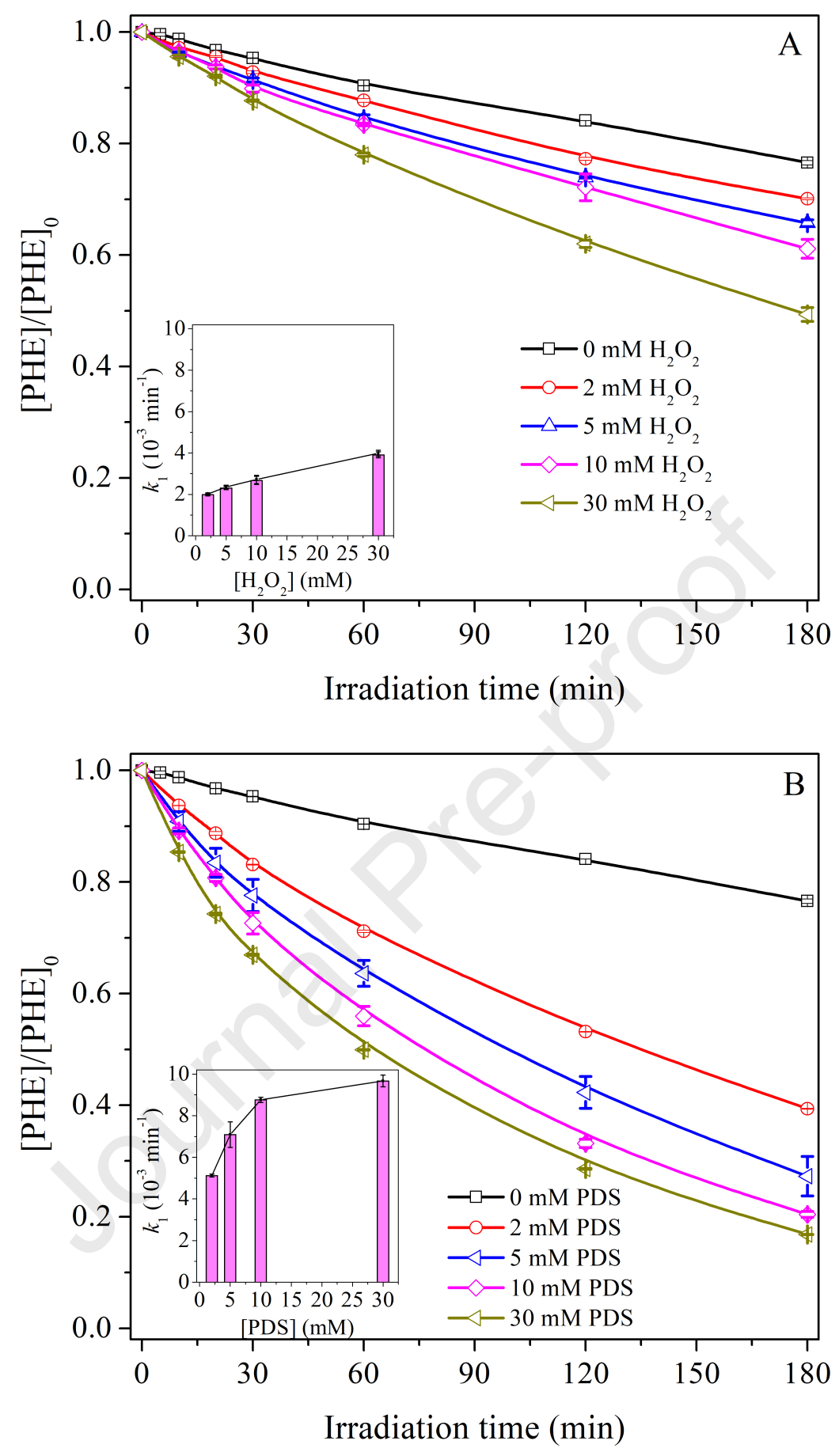

Figure 2. Influence of oxidant concentration on the photo-degradation of PHE. Inserts are the corresponding pseudo first order rate constants. A) $\mathrm{UVB} / \mathrm{H}_{2} \mathrm{O}_{2}$; B) $\mathrm{UVB} / \mathrm{PDS}$. Initial conditions are $[\mathrm{PHE}]=10 \mathrm{mg} \mathrm{L}^{-1},[\mathrm{TW} 80]=0.5 \mathrm{~g} \mathrm{~L}^{-1}, \mathrm{pH} 3.3 \pm 0.1$. 

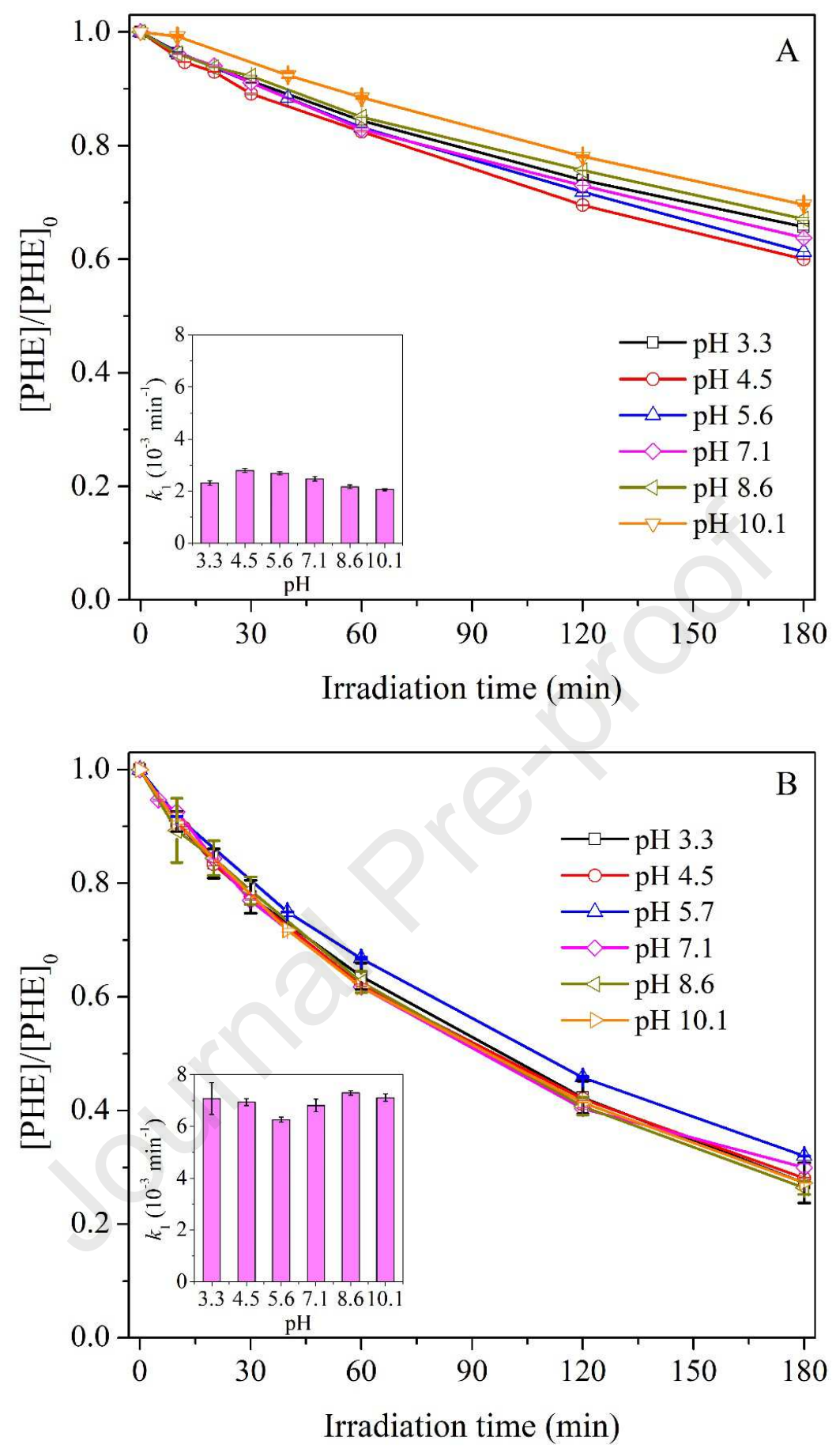

Figure 3. Influence of initial solution $\mathrm{pH}$ on the photo-degradation of PHE. Inserts are the corresponding pseudo first order rate constants. A) $\mathrm{UVB} / \mathrm{H}_{2} \mathrm{O}_{2}$; B) UVB/PDS. Initial conditions are: $[\mathrm{PHE}]=10 \mathrm{mg} \mathrm{L}^{-1}$, $[\mathrm{TW} 80]=0.5 \mathrm{~g} \mathrm{~L}^{-1},[\mathrm{PDS}]=\left[\mathrm{H}_{2} \mathrm{O}_{2}\right]=5$ $\mathrm{mM}$. 

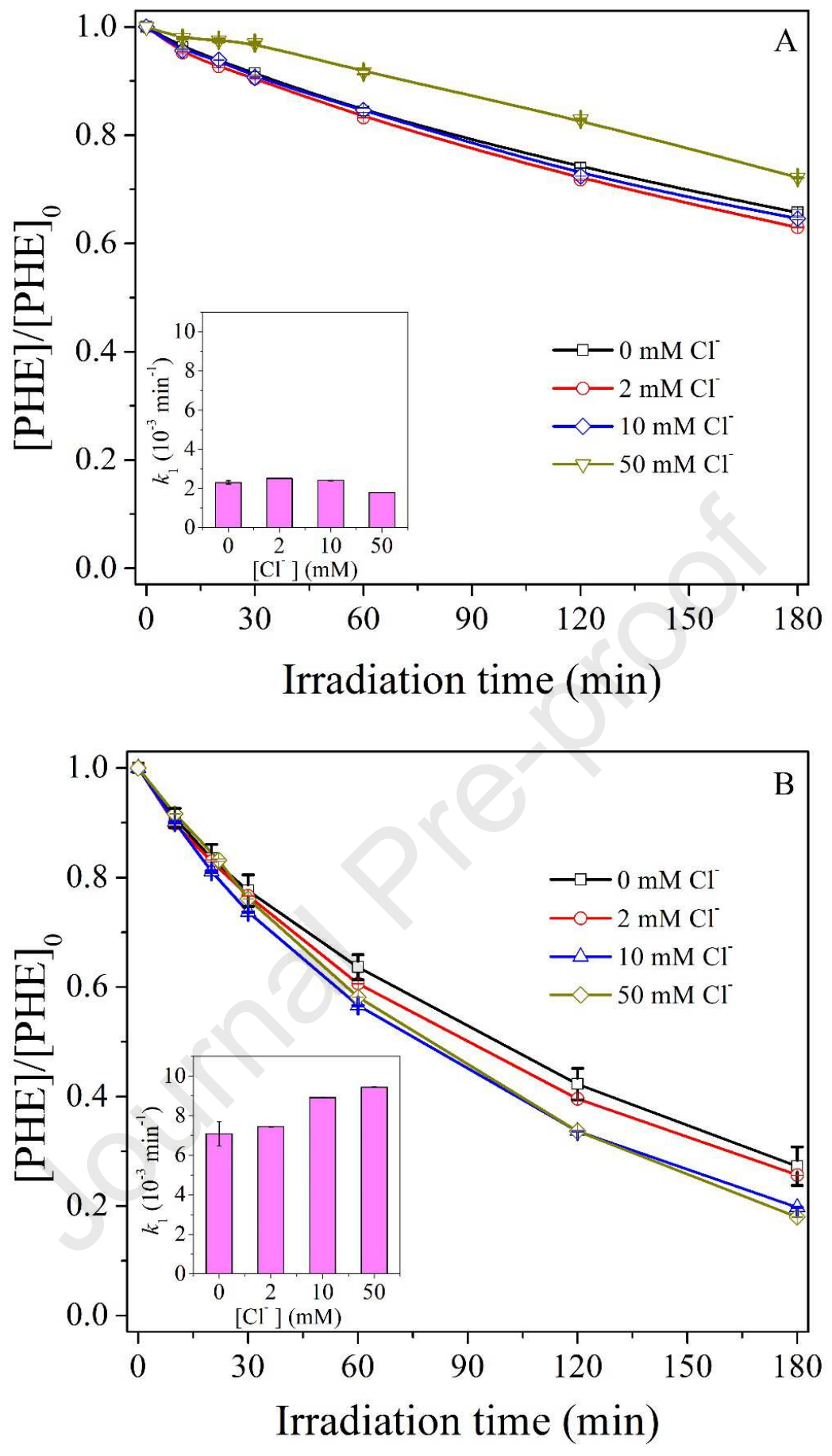

Figure 4. Influence of $\mathrm{Cl}^{-}$concentration on the photo-degradation of PHE. A) $\mathrm{UVB} / \mathrm{H}_{2} \mathrm{O}_{2}$; B) UVB/PDS. Insets are the corresponding first-order rate constants. Initial conditions are: $[\mathrm{PHE}]=10 \mathrm{mg} \mathrm{L}^{-1}$, $[\mathrm{TW} 80]=0.5 \mathrm{~g} \mathrm{~L}^{-1},[\mathrm{PDS}]=\left[\mathrm{H}_{2} \mathrm{O}_{2}\right]=5$ $\mathrm{mM}, \mathrm{pH} 3.3 \pm 0.1$. 

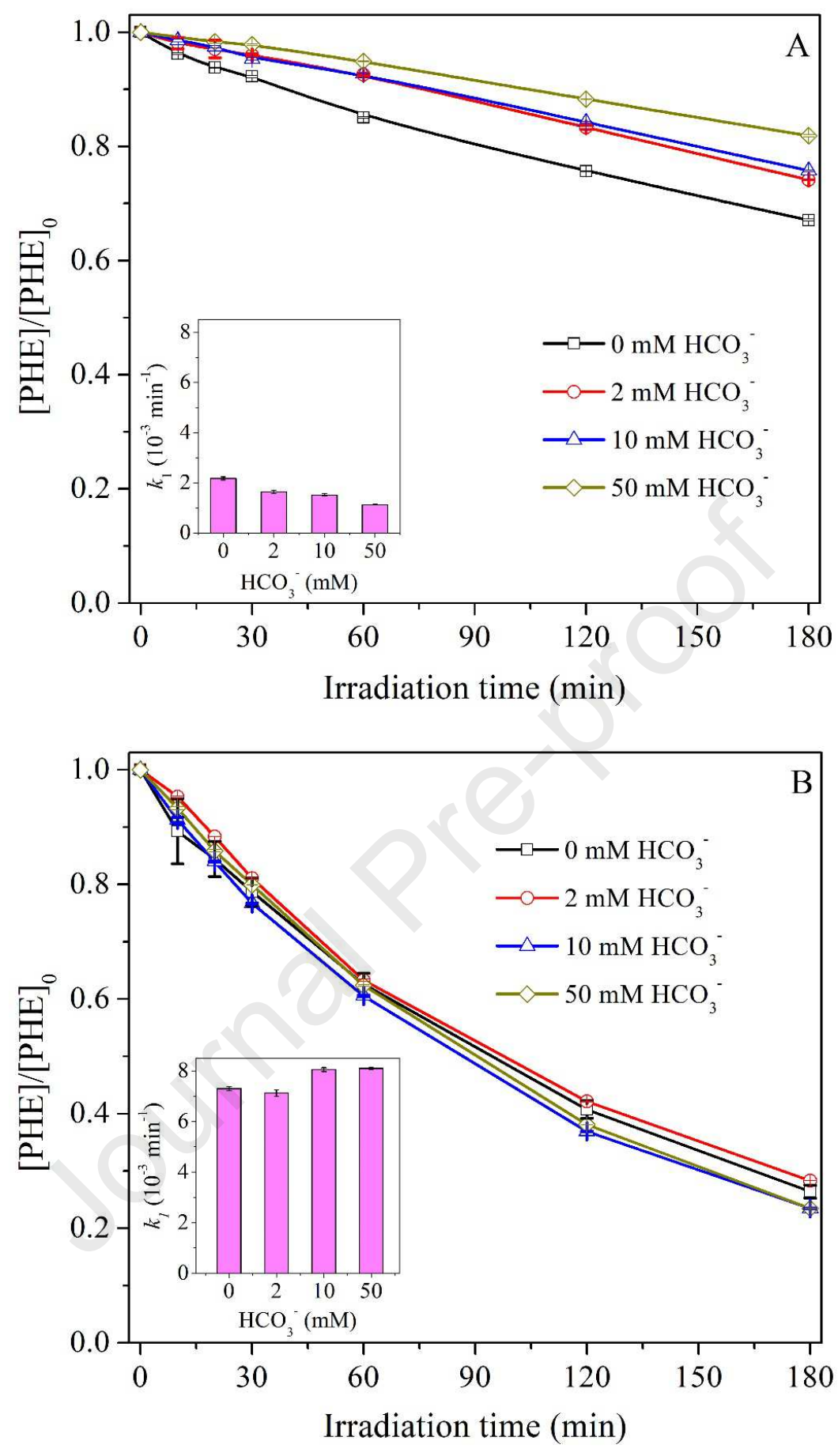

Figure 5. Influence of $\mathrm{HCO}_{3}{ }^{-}$concentration on the photo-degradation of PHE. A) $\mathrm{UVB} / \mathrm{H}_{2} \mathrm{O}_{2}$; B) UVB/PDS. Insets are the corresponding first-order rate constants. Initial conditions are: $[\mathrm{PHE}]=10 \mathrm{mg} \mathrm{L}^{-1},[\mathrm{TW} 80]=0.5 \mathrm{~g} \mathrm{~L}^{-1},[\mathrm{PDS}]=\left[\mathrm{H}_{2} \mathrm{O}_{2}\right]=5$ $\mathrm{mM}, \mathrm{pH} 8.6 \pm 0.1$. 

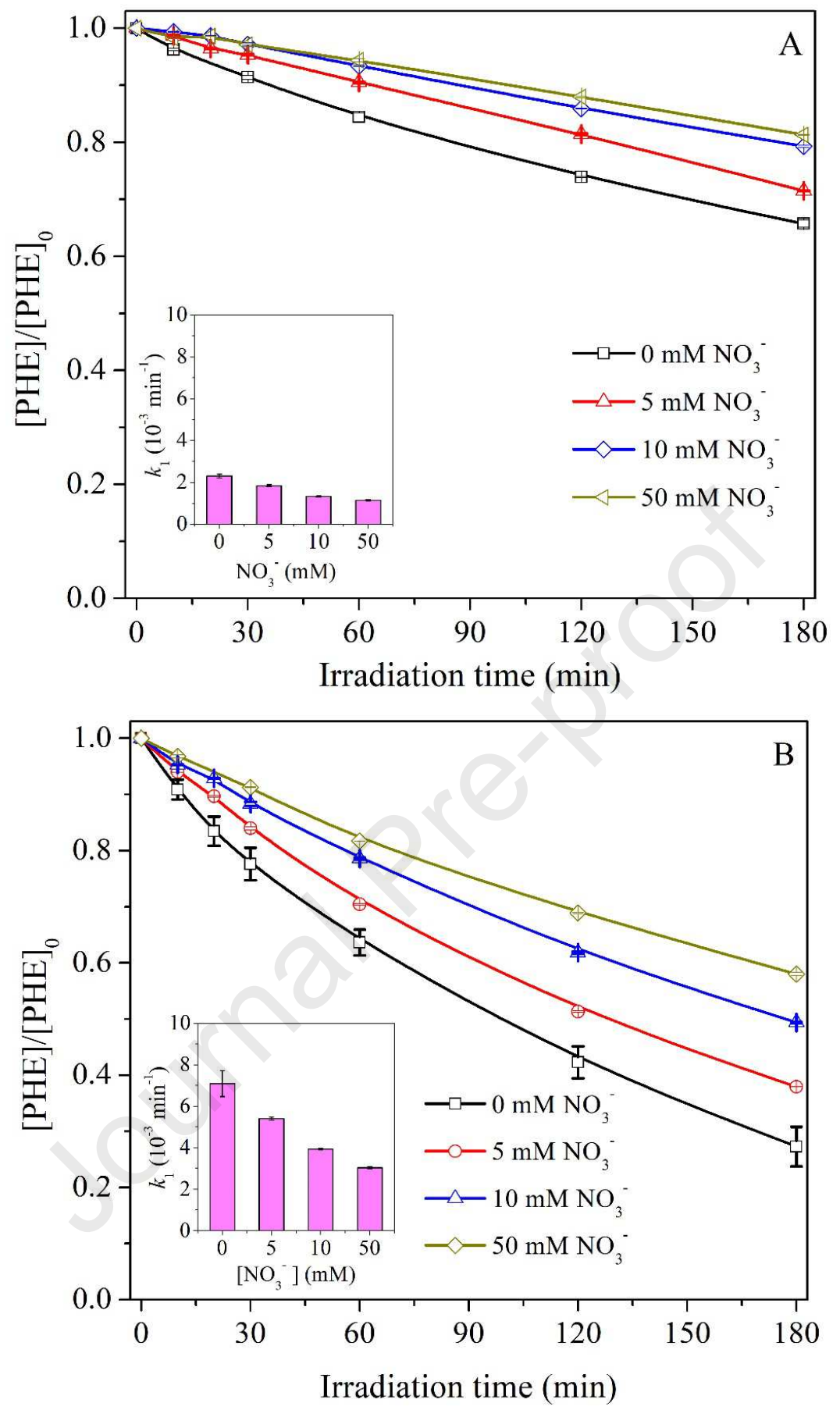

Figure 6. Influence of $\mathrm{NO}_{3}{ }^{-}$concentration on the photo-degradation of PHE. A) $\left.\mathrm{UVB} / \mathrm{H}_{2} \mathrm{O}_{2} ; \mathrm{B}\right) \mathrm{UVB} / \mathrm{PDS}$. Insets are the corresponding first-order rate constants. Initial conditions are: $[\mathrm{PHE}]=10 \mathrm{mg} \mathrm{L}^{-1}$, $[\mathrm{TW} 80]=0.5 \mathrm{~g} \mathrm{~L}^{-1},[\mathrm{PDS}]=\left[\mathrm{H}_{2} \mathrm{O}_{2}\right]=5$ $\mathrm{mM}, \mathrm{pH} 3.3 \pm 0.1$. 


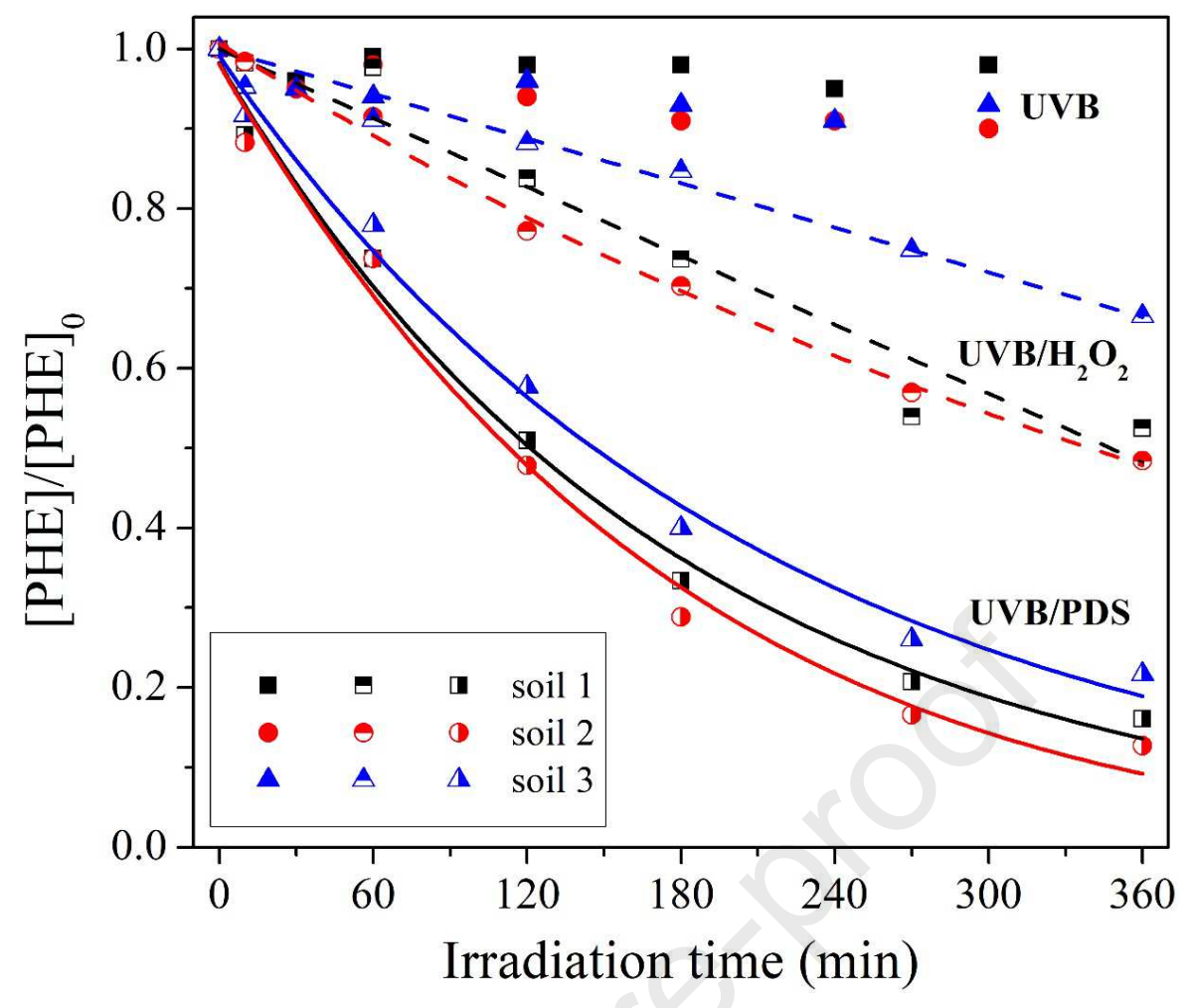

Figure 7. Degradation of PHE with three real SW effluents in different systems. Initial conditions are $[\mathrm{PDS}]=\left[\mathrm{H}_{2} \mathrm{O}_{2}\right]=5 \mathrm{mM}$. 


\section{Highlights}

$>$ PDS is more efficient than $\mathrm{H}_{2} \mathrm{O}_{2}$ for UVB decay of PHE in soil washing (SW) effluent

$>\mathrm{UVB} / \mathrm{PDS}$ process is less impacted by the inorganic ions $\left(\mathrm{Cl}^{-}, \mathrm{HCO}_{3}{ }^{-}\right.$and $\left.\mathrm{NO}_{3}{ }^{-}\right)$

UVB/PDS is a promising and sustainable process for real SW effluent treatment 


\section{Figure captions}

Figure 1. Degradation of PHE in the presence of TW80 in different systems. Inserts are the corresponding pseudo-first order rate constants. Initial conditions are $[\mathrm{PHE}]=$ $10 \mathrm{mg} \mathrm{L}^{-1},[\mathrm{TW} 80]=0.5 \mathrm{~g} \mathrm{~L}^{-1},[\mathrm{PDS}]=\left[\mathrm{H}_{2} \mathrm{O}_{2}\right]=5 \mathrm{mM}, \mathrm{pH} 3.3 \pm 0.1$.

Figure 2. Influence of oxidant concentration on the photo-degradation of PHE. Inserts are the corresponding pseudo first order rate constants. A) $\mathrm{UVB} / \mathrm{H}_{2} \mathrm{O}_{2}$; B) $\mathrm{UVB} / \mathrm{PDS}$. Initial conditions are $[\mathrm{PHE}]=10 \mathrm{mg} \mathrm{L}^{-1},[\mathrm{TW} 80]=0.5 \mathrm{~g} \mathrm{~L}^{-1}, \mathrm{pH} 3.3 \pm 0.1$.

Figure 3. Influence of initial solution $\mathrm{pH}$ on the photo-degradation of PHE. Inserts are the corresponding pseudo first order rate constants. A) $\mathrm{UVB} / \mathrm{H}_{2} \mathrm{O}_{2}$; B) $\mathrm{UVB} / \mathrm{PDS}$. Initial conditions are: $[\mathrm{PHE}]=10 \mathrm{mg} \mathrm{L}^{-1},[\mathrm{TW} 80]=0.5 \mathrm{~g} \mathrm{~L}^{-1},[\mathrm{PDS}]=\left[\mathrm{H}_{2} \mathrm{O}_{2}\right]=5$ $\mathrm{mM}$.

Figure 4. Influence of $\mathrm{Cl}^{-}$concentration on the photo-degradation of PHE. A) $\mathrm{UVB} / \mathrm{H}_{2} \mathrm{O}_{2}$; B) $\mathrm{UVB} / \mathrm{PDS}$. Insets are the corresponding first-order rate constants. Initial conditions are: $[\mathrm{PHE}]=10 \mathrm{mg} \mathrm{L}^{-1},[\mathrm{TW} 80]=0.5 \mathrm{~g} \mathrm{~L}^{-1},[\mathrm{PDS}]=\left[\mathrm{H}_{2} \mathrm{O}_{2}\right]=5$ $\mathrm{mM}, \mathrm{pH} 3.3 \pm 0.1$.

Figure 5. Influence of $\mathrm{HCO}_{3}{ }^{-}$concentration on the photo-degradation of PHE. A) $\mathrm{UVB} / \mathrm{H}_{2} \mathrm{O}_{2}$; B) UVB/PDS. Insets are the corresponding first-order rate constants. Initial conditions are: $[\mathrm{PHE}]=10 \mathrm{mg} \mathrm{L}^{-1},[\mathrm{TW} 80]=0.5 \mathrm{~g} \mathrm{~L}^{-1},[\mathrm{PDS}]=\left[\mathrm{H}_{2} \mathrm{O}_{2}\right]=5$ $\mathrm{mM}, \mathrm{pH} 8.6 \pm 0.1$.

Figure 6. Influence of $\mathrm{NO}_{3}{ }^{-}$concentration on the photo-degradation of PHE. A) $\mathrm{UVB} / \mathrm{H}_{2} \mathrm{O}_{2}$; B) UVB/PDS. Insets are the corresponding first-order rate constants. Initial conditions are: $[\mathrm{PHE}]=10 \mathrm{mg} \mathrm{L}^{-1},[\mathrm{TW} 80]=0.5 \mathrm{~g} \mathrm{~L}^{-1},[\mathrm{PDS}]=\left[\mathrm{H}_{2} \mathrm{O}_{2}\right]=5$ $\mathrm{mM}, \mathrm{pH} 3.3 \pm 0.1$.

Figure 7. Degradation of PHE with three real SW effluents in different systems. Initial conditions are $[\mathrm{PDS}]=\left[\mathrm{H}_{2} \mathrm{O}_{2}\right]=5 \mathrm{mM}$. 